\title{
Brief interventions for drink-driver offenders in Slovenia
}

Marko Kolšek

From International Network on Brief Interventions for Alcohol and Other Drugs (INEBRIA) Meeting 2011 Boston, MA, USA. 21-23 September 2011

Drunk driving remains a problem in Slovenia despite the 2008 Law on Road Safety, which enables the police to retain intoxicated drivers for 6-12 hours who have a blood alcohol level of more than $1.5 \mathrm{~g} / \mathrm{kg}$. Every night, approximately 20 drivers pass a night at the police station (the Slovenian population is 2 million). To reduce drunk driving, an updated Law on Road Safety was approved in December 2010, which introduced higher fines and extra penalty points for drunk driving. It also offered a provision for drunk drivers to receive medical examinations and counseling from their family doctors. Short courses and printed materials for Slovenian family physicians were prepared and disseminated in the spring of 2011 to introduce them to basic principles of brief intervention. In October 2011, the examination and counseling program was launched, and data collection for a study to assess results is underway.

Published: 9 October 2012

Submit your next manuscript to BioMed Central and take full advantage of:

- Convenient online submission

- Thorough peer review

- No space constraints or color figure charges

- Immediate publication on acceptance

- Inclusion in PubMed, CAS, Scopus and Google Scholar

- Research which is freely available for redistribution

\section{Biomed Central}

